\title{
Assessment of the Spatial Effects of Land-Consolidation Works Carried out in Poland in the Years 2007-2013**
}

\begin{abstract}
A large percentage of rural areas in Poland require deep structural changes. Such lands (in particular, areas in southern and southeastern Poland) are characterized by the excessive fragmentation of land owned by individual farmers, a disadvantageous expanse of lands, and the poor condition of the technical and institutional infrastructures (or a lack thereof). Disadvantageous demographic processes (such as the migration of inhabitants from villages to cities and aging of the local population) also occur in those areas. It is possible to improve the current conditions through the effective implementation of rural-area development programs, such as the implementation of land-consolidation works.

The objective of this work is to assess the spatial effects of land-consolidation works carried out in Poland. The research was based on a representative sample of 38 study objects located in different parts of Poland. For the assumed study objects, changes of the basic parameters that characterize the spatial structure of the lands were examined. These resulted from the performed land-consolidation process: the coefficient of the decrease in the total number of parcels and the coefficient of the increase in the size of the average plot for the examined objects.
\end{abstract}

Keywords: land consolidation, spatial effects of land consolidation, rural development, rural areas in Poland

* Warsaw University of Technology, Faculty of Geodesy and Cartography, Department of Cadastre and Land Management, Warsaw, Poland

** This work is financed from funds of Dean's Grant realized at Warsaw University of Technology, allocated for the year 2016, entitled "Ocena efektów gospodarczych prac scaleniowych realizowanych w Polsce" No 504/02432/1060/42.000100. 


\section{Introduction}

Polish accession to the European Union allowed us to cover Polish agriculture by supporting instruments of the Common Agricultural Policy and implementing operations directed towards the sustainable and multi-functional development of rural areas [7]. Slow, positive structural changes of the Polish farms may be observed. The results of the Agricultural Census of 2010 [2] point to the gradual concentration of farms, which - as a result of modernization and specialization - are adapting to European Union standards. However, a big part of the Polish rural areas still requires deep structural transformation [8]. Disadvantageous demographic processes still occur in the rural areas in Poland (such as the migration of inhabitants to cities and aging of the local inhabitants), and a considerable percentage of farms are small, semi-subsistence, and economically ineffective farms [4]. According to data from 2010 [3], more than $32 \%$ of the total number of farms produce less than 2,000 Euros of SO (the economic value of a farm, calculated on the basis of Production Standards - SO). Compared to the agriculture of other EU countries, Polish agriculture is characterized by one of the worst land-use structures [1]. A high regional diversification of the structure of plots and farms has occured in Poland [11]. In particular, areas in the southern and southeastern parts of Poland are characterized by the excessive fragmentation of lands owned by individual farmers, a disadvantageous expanse of lands in farms, and the poor condition of the technical and institutional infrastructures (or a lack thereof) [9]. Therefore, the use of plots in the above-mentioned areas is not as efficient as in the case of plots with the correct shape and optimum surface area [10]. A strong influence of the basic parameters characterizing the spatial shape expanse of land plots in farms (such as the extension and perimeter of plots in the local farms as well as the surface area, length, width, and perimeter of the plots of non-residents) on the costs and efficiency of agricultural production has been proven [10].

It is possible to improve the existing conditions through the effective implementation of rural-area development programs, such as the implementation of land-consolidation works. Land consolidation is a tool that allows for effecting complex improvements in the spatial structure of farms within an entire village [6]; the effective arrangement of lands is one of the most-important factors that facilitates maintaining effective agricultural production [5].

\section{Data and Methodology}

The objective of the research is to assess the spatial effects of land-consolidation works carried out in Poland. Research works were based on a representative sample of 38 randomly selected land-consolidation objects from different parts of Poland (Fig. 1) where land-consolidation works were performed within the RADP (Rural Areas Development Program) 2007-2013 programming period. 


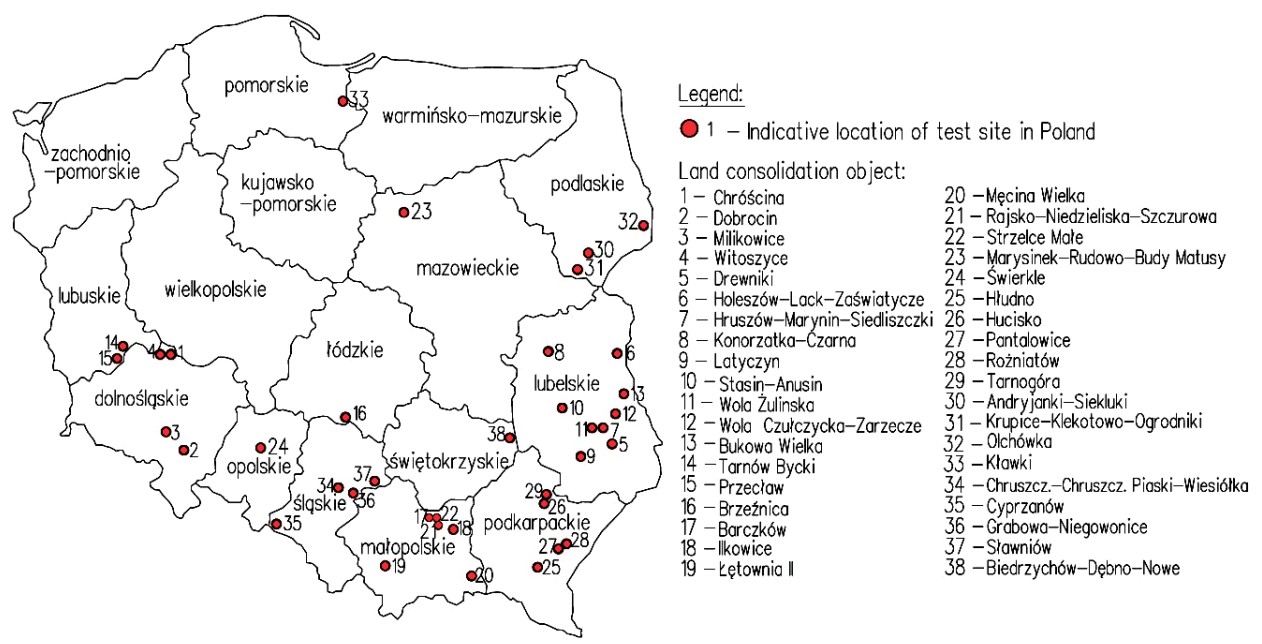

Fig. 1. Approximate locations of test objects in Poland

The assumed number of test objects in a voivodeship was proportional to the area of land-consolidation works carried out in a voivodeship during the programming period of RADP 2007-2013 (Tab. 1).

Table 1. Number of tested land-consolidation objects in specific voivodeships, calculated on basis of lands consolidated in period 2007-2013

\begin{tabular}{|c|c|c|c|c|}
\hline No. & Voivodeship & $\begin{array}{l}\text { Land-consolidation } \\
\text { areas in period } \\
2007-2013 \text { [ha] }^{*} \\
\end{array}$ & $\begin{array}{c}\text { Percentage share in total areas } \\
\text { consolidated in Poland in period } \\
2007-2013[\%]\end{array}$ & $\begin{array}{l}\text { The number } \\
\text { of approved } \\
\text { test objects }\end{array}$ \\
\hline 1 & Dolnośląskie & 10,873 & 11.7 & 4 \\
\hline 2 & Kujawsko-Pomorskie & 0 & 0.0 & 0 \\
\hline 3 & Lubelskie & 21,992 & 23.7 & 9 \\
\hline 4 & Lubuskie & 4,235 & 4.6 & 2 \\
\hline 5 & Łódzkie & 2,483 & 2.7 & 1 \\
\hline 6 & Małopolskie & 16,284 & 17.6 & 6 \\
\hline 7 & Mazowieckie & 2,428 & 2.6 & 1 \\
\hline 8 & Opolskie & 1,299 & 1.4 & 1 \\
\hline 9 & Podkarpackie & 13,422 & 14.5 & 5 \\
\hline 10 & Podlaskie & 6,318 & 6.8 & 3 \\
\hline 11 & Pomorskie & 3,189 & 3.4 & 1 \\
\hline 12 & Śląskie & 8,843 & 9.5 & 4 \\
\hline 13 & Świętokrzyskie & 1,321 & 1.4 & 1 \\
\hline 14 & Warmińsko-Mazurskie & 10 & 0.0 & 0 \\
\hline 15 & Wielkopolskie & 0 & 0.0 & 0 \\
\hline 16 & Zachodniopomorskie & 7 & 0.0 & 0 \\
\hline & Total: & 92,704 & 100.0 & 38 \\
\hline
\end{tabular}

* based on data from Ministry of Agriculture and Rural Development 
The total analyzed area of land consolidation (35,283 ha) equaled $38.06 \%$ of the total area of lands covered by land-consolidation works within RADP 2007-2013. Tests were performed on the basis of land-consolidation documentation obtained from the Department of Management of Lands of the Ministry of Agriculture and Rural Development, from District Marshall (Starost) Offices, and from Voivodeship Offices of Geodesy and Rural Areas.

For the tested objects, changes in the basic parameters of the spatial structure of lands resulting from performed land-consolidation works were examined. Based on the total number of plots before and after land consolidation, the percentage share of the reduction of the number of plots as a result of land consolidation, $C_{1}(1)$, was calculated:

$$
C_{1}=\frac{N_{B}-N_{A}}{N_{B}} \cdot 100 \%
$$

where:

$N_{B}$ - total number of plots in the study area before land consolidation,

$N_{A}$ - total number of plots in the study area after land consolidation.

The coefficient of the increase in the average plot size for the study object, $C_{2}(2)$, was calculated on the basis of the average plot size before and after land consolidation:

$$
C_{2}=\frac{A_{A}}{A_{B}}
$$

where:

$A_{B}$ - the average plot size in the study area before land consolidation, $A_{A}$ - the average plot size in the study area after land consolidation.

\section{Results}

Results of the tests are presented in tabular form (Tab. 2).

The average values of the percentile coefficient of the reduction of the number of plots $C_{1}$ vary between $11.6 \%$ and $72.3 \%$ in particular voivodeships (Fig. 2). This coefficient has the highest value $(72.3 \%)$ for study object 38 in Świętokrzyskie voivodeship (Biedrzychów-Dębno-Nowe, Ożarów Municipality). In the case of study object 31 (Krupice-Klekotowo-Ogrodniki, Siemiatycze Municipality, Podlaskie voivodeship), the value of this coefficient was negative $(-3.9 \%)$; this could prove negative effects of the land-consolidation process. However, this was caused by the presence of the Land Community of the village of Ogrodniki (6 plots of a total size of 228 ha before land consolidation); this community was liquidated as a result of land consolidation. 
Table 2. Spatial effects obtained for study areas as a result of land-consolidation works

\begin{tabular}{|c|c|c|c|c|c|c|c|}
\hline \multirow{2}{*}{$\begin{array}{l}\text { No. of } \\
\text { study } \\
\text { object }\end{array}$} & \multirow{2}{*}{$\begin{array}{l}\text { Land-consolidation } \\
\text { (LC) area [ha] }\end{array}$} & \multicolumn{2}{|c|}{$\begin{array}{l}\text { Total number } \\
\text { of plots }\end{array}$} & \multirow{2}{*}{$\begin{array}{c}\text { Coef. } \\
C_{1} \\
{[\%]}\end{array}$} & \multicolumn{2}{|c|}{$\begin{array}{c}\text { The average plot size } \\
\text { [ha] }\end{array}$} & \multirow{2}{*}{$\begin{array}{c}\text { Coef. } \\
\mathrm{C}_{2}\end{array}$} \\
\hline & & before LC & after LC & & Before LC & After LC & \\
\hline 1 & 1,452 & 1,186 & 603 & 49.2 & 1.22 & 2.41 & 2.0 \\
\hline 2 & 1,246 & 714 & 516 & 27.7 & 1.75 & 2.41 & 1.4 \\
\hline 3 & 947 & 578 & 450 & 22.1 & 1.64 & 2.11 & 1.3 \\
\hline 4 & 1,246 & 1,113 & 506 & 54.5 & 1.12 & 2.46 & 2.2 \\
\hline 5 & 1,350 & 2,670 & 1,653 & 38.1 & 0.51 & 0.82 & 1.6 \\
\hline 6 & 1,120 & 957 & 687 & 28.2 & 1.17 & 1.63 & 1.4 \\
\hline 7 & 1,119 & 2,094 & 1,136 & 45.7 & 0.53 & 0.99 & 1.8 \\
\hline 8 & 534 & 1,292 & 952 & 26.3 & 0.41 & 0.56 & 1.4 \\
\hline 9 & 973 & 3,819 & 2,640 & 30.9 & 0.25 & 0.37 & 1.4 \\
\hline 10 & 397 & 1,052 & 443 & 57.9 & 0.38 & 0.90 & 2.4 \\
\hline 11 & 533 & 1,230 & 656 & 46.7 & 0.43 & 0.81 & 1.9 \\
\hline 12 & 515 & 1,796 & 826 & 54.0 & 0.29 & 0.62 & 2.2 \\
\hline 13 & 1,382 & 1,227 & 873 & 28.9 & 1.13 & 1.58 & 1.4 \\
\hline 14 & 640 & 502 & 249 & 50.4 & 1.27 & 2.57 & 2.0 \\
\hline 15 & 922 & 214 & 96 & 55.1 & 4.31 & 9.60 & 2.2 \\
\hline 16 & 1,213 & 3,479 & 1,305 & 62.5 & 0.35 & 0.93 & 2.7 \\
\hline 17 & 213 & 418 & 305 & 27.0 & 0.51 & 0.70 & 1.4 \\
\hline 18 & 480 & 1410 & 1,015 & 28.0 & 0.34 & 0.47 & 1.4 \\
\hline 19 & 981 & 5,337 & 3,095 & 42.0 & 0.18 & 0.32 & 1.7 \\
\hline 20 & 937 & 1,187 & 711 & 40.1 & 0.79 & 1.32 & 1.7 \\
\hline 21 & 590 & 1,944 & 593 & 69.5 & 0.30 & 1.00 & 3.3 \\
\hline 22 & 564 & 1,364 & 817 & 40.1 & 0.41 & 0.69 & 1.7 \\
\hline 23 & 413 & 622 & 275 & 55.8 & 0.66 & 1.50 & 2.3 \\
\hline 24 & 246 & 445 & 258 & 42.0 & 0.55 & 0.95 & 1.7 \\
\hline 25 & 1,233 & 5,316 & 3,376 & 36.5 & 0.23 & 0.37 & 1.6 \\
\hline 26 & 438 & 2,583 & 1,563 & 39.5 & 0.17 & 0.28 & 1.7 \\
\hline 27 & 1,142 & 3,433 & 2,281 & 33.6 & 0.33 & 0.50 & 1.5 \\
\hline 28 & 511 & 1,373 & 879 & 36.0 & 0.37 & 0.58 & 1.6 \\
\hline 29 & 658 & 1,881 & 1,682 & 10.6 & 0.35 & 0.39 & 1.1 \\
\hline 30 & 2,321 & 1,840 & 1,372 & 25.4 & 1.26 & 1.69 & 1.3 \\
\hline 31 & 1,609 & 1,167 & 1,212 & -3.9 & 1.38 & 1.33 & 1.0 \\
\hline 32 & 365 & 696 & 550 & 21.0 & 0.52 & 0.66 & 1.3 \\
\hline 33 & 345 & 155 & 137 & 11.6 & 2.23 & 2.52 & 1.1 \\
\hline 34 & 1,005 & 4,156 & 1,993 & 52.0 & 0.24 & 0.50 & 2.1 \\
\hline 35 & 559 & 909 & 569 & 37.4 & 0.61 & 0.98 & 1.6 \\
\hline 36 & 3,289 & 12,956 & 6,043 & 53.4 & 0.25 & 0.54 & 2.1 \\
\hline 37 & 711 & 2,169 & 1,220 & 43.8 & 0.33 & 0.58 & 1.8 \\
\hline 38 & 1,084 & 7,145 & 1,980 & 72.3 & 0.15 & 0.55 & 3.6 \\
\hline Total: & 35,283 & Avera & ge $C_{1}$ : & 39,3 & Avera & se $C_{2}$ : & 1.8 \\
\hline
\end{tabular}

Source: own elaboration based on data from Ministry of Agriculture and Rural Development, Regional Bureaus of Surveying and Agricultural Areas and District Offices 
Two hundred forty-seven plots were distinguished within the area of the Land Community in the village of Ogrodniki, including 14 plots as roads, which were to serve for the newly distinguished plots (own research based on land register data before and after land consolidation). Based on the performed analyses, it may be estimated that the average coefficient of reduction of the total number of plots for the period of $2007-2013$ equals $39.3 \%$.

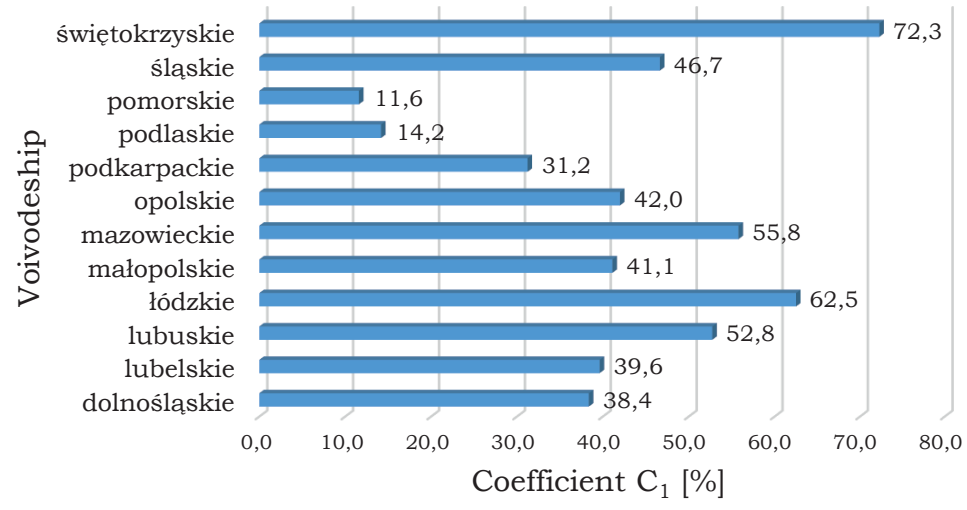

Fig. 2. Average coefficient of reduction of total number of plots for land-consolidation object in analyzed voivodeships

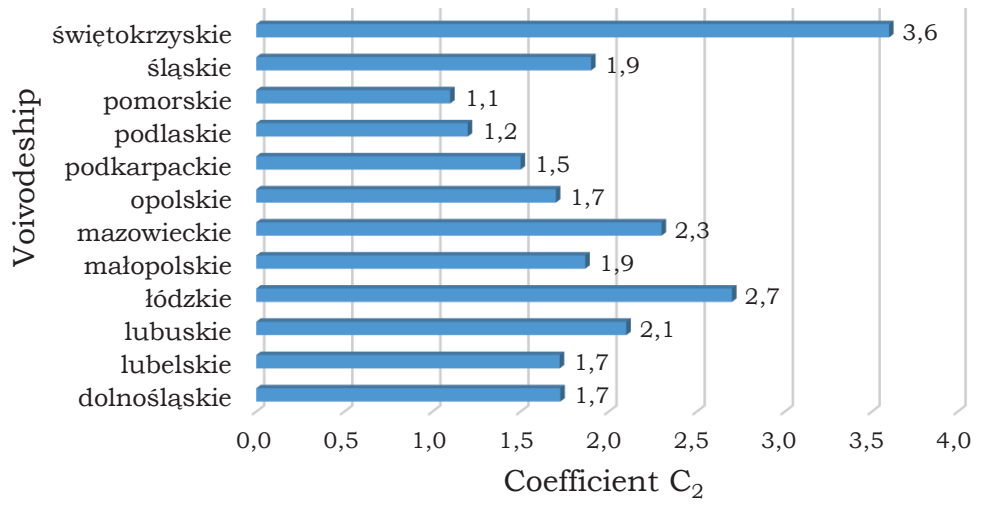

Fig. 3. Average coefficient of increase of average plot size for land-consolidation object in analyzed voivodeships

The average values of the coefficient of the increase in the size of an average plot for study object $C_{2}$ in particular voivodeships (Fig. 3) vary between 1.1 (Pomorskie voivodeship) to 3.6 (Świętokrzyskie voivodeship). For each analyzed study object, the coefficient value was higher than 1.0 (for each object, the average plot size was increased as a result of land-consolidation works). The estimated value of the 
coefficient of the increase in the size of an average plot for operations performed in the period of 2007-2013 in Poland equals 1.8. This proves that the size of an average plot almost doubled as a result of land consolidation.

\section{Conclusions}

The mostly apparent effects of land-consolidation works include the reduction of the number of plots, which directly results in a reduction of the number of plots in particular farms. According to the performed tests, the total number of plots for an object was reduced by approx. $39.3 \%$ as a results of land-consolidation works carried out in Poland during RADP (Rural Areas Development Program) 2007-2013. The coefficient of the increase in the average plot size was estimated at a level of 1.8. The obtained results point to the high effectiveness of the land-consolidation works carried out in Poland in terms of management in agriculture.

It should be stressed that the analyzed coefficients should not be the only measure of the correctness and effectiveness of the performed land-consolidation works. Study object no. 31 may be used as an example. The $C_{1}$ coefficient equaled $-3.9 \%$, and $C_{2}-$ to 1.0 for that object. However, the effects of the land-consolidation works achieved for that object should not be considered negative. The negative $C_{1}$ value resulted from the specific features of the land-consolidation object. A total of $14.2 \%$ of the total area of land consolidation covered 6 plots included in the Land Community of the village of Ogrodniki (228 ha). As a result of land consolidation, the Land Community was liquidated, and a field equivalent was distinguished for each of the 92 entitled participants according to the size of their shares (247 plots were distinguished, including 14 plots for roads; the access to public roads was ensured for each newly designed plot).

According to Woch [12], the current methods of assessing land-consolidation works are based on a partial assessment of economic effects (the coefficient of the reduction of the number of plots and the coefficient of the increase of their sizes) and on the individual assessment of participants of land-consolidation works; this sometimes leads to the positive assessment of projects that improve the field expanse to a minor extent only. However, the performed research works allows us to state that, for each analyzed object, land-consolidation works contributed to improvements in the spatial structure of farms and, therefore, to improvements in farming conditions. Besides improvements in the analyzed parameters $\left(C_{1}\right.$ and $\left.C_{2}\right)$, the land-consolidation works carried out in Poland in the period of 2007-2013 resulted in many positive changes in the spatial structure of lands. Land-consolidation works performed for the analyzed study objects contributed to improvements in the field expanse of particular farms and influenced the effectiveness of the agricultural production of those farms. Newly designed plots were usually bigger and were characterized by more-convenient locations. Another important element was the correction of borders, 
aimed at eliminating the irregular shapes of plots and arranging for a more-effective division of the agricultural space. Changes in plot configurations on a farm allows for its adaptation to a new system of roads and ditches as well as the elimination of inconveniences related to the use of lands.

\section{References}

[1] Eurostat: Agriculture, forestry and fishery statistics. Publications Office of the European Union, Luxembourg 2013, [on-line:] http://ec.europa.eu/eurostat/ documents [access: September, 2016].

[2] GUS: Powszechny Spis Rolny 2010. Raport z wyników [National Agricultural Census 2010 - Report of Results]. Warszawa 2011, [on-line:] http://stat.gov.pl [access: September, 2016].

[3] GUS: Powszechny Spis Rolny 2010. Gospodarstwa rolne w Polsce na tle gospodarstw Unii Europejskiej - wptyw WPR [National Agricultural Census 2010. Farms in Poland to Other Farms in EU - the Influence of CAP]. Warszawa 2013, [on-line:] http://stat.gov.pl [access: September, 2016].

[4] Halamska M.: Drobne gospodarstwa $i$ ich właściciele na polskiej wsi. Refleksje socjologiczne [Small Farms and Their Owners in the Polish Countryside. Sociological Reflections]. Annales Universitatis Mariae Curie-Skłodowska. Sectio I Philosophia-Sociologia, vol. 36, [cz.] 2, 2011, pp. 113-129.

[5] Hopfer A., Urban M.: Geodezyjne urządzanie terenów rolnych [Geodetic rural areas management]. Państwowe Wydawnictwo Naukowe, Warszawa, 1984, p. 630.

[6] Janus J.: Ocena zmian struktury przestrzennej wsi Lipnica Wielka będacych efektem scalenia gruntów [Assessment of Changes in Spatial Structure of Lipnica Wielka Village Resulting from Land Consolidation]. Infrastruktura i Ekologia Terenów Wiejskich, nr 2, 2011, pp. 71-81.

[7] Michalczyk J.: Ewolucja polityki rolnej Unii Europejskiej na tle koncepcji zrównoważonego rozwoju [The Evolution of European's Agricultural Policy Against the Background of the Conception of Sustainable Development]. Prace Naukowe Uniwersytetu Ekonomicznego we Wrocławiu, nr 369, 2014, pp. 333-349.

[8] Siemiński J.L.: Idea "rozwoju zrównoważonego i trwałego" obszarów wiejskich w Polsce na tle innych koncepcji. Ujęcie planistyczne. (Część I) [Idea of Sustainable Rural Development in Poland Against the Background of Other Conceptions. Planning Approach (Part 1)]. Infrastruktura i Ekologia Terenów Wiejskich, nr 2, 2008, pp. 7-25.

[9] Sobolewska-Mikulska K.: Metodyka rozwoju obszarów wiejskich z uwzględnieniem wybranych procedur geodezyjnych w aspekcie integracji $z$ Unia Europejska [Methodology of rural development with emphasis on selected geodetic procedures in terms of integration with the European Union]. Prace Naukowe - Politechnika Warszawska. Geodezja, z. 44, 2009, pp. 3-148. 
[10] Sobolewska-Mikulska K. (red.), Balawejder M., Bielska A., Cymerman R., Gniadek J., Mazur A., Ogryzek M., Pijanowski J.M., Stańczuk-Gałwiaczek M., Taszakowski J.: Wspótczesne scalania gruntów w kształtowaniu granic rolniczej przestrzeni produkcyjnej [Modern land consolidation in shaping the boundaries of agricultural production space]. Geodezja i Kartografia - Wydział Geodezji i Kartografii Politechniki Warszawskiej, t. 1, Oficyna Wydawnicza Politechniki Warszawskiej, Warszawa 2015.

[11] Woch F.: Perspektywy zmian strukturalnych na obszarach wiejskich [Prospects for structural changes in rural areas]. [in:] Woch F. (red.), Kompleksowe scalanie gruntów rolnych i leśnych oraz jego wpływ na środowisko [Comprehensive land consolidation of agricultural and forest land and its impact on the environment]. Materiały Szkoleniowe - Instytut Uprawy, Nawożenia i Gleboznawstwa, 93, Wydawnictwo IUNG-PIB, Puławy 2006, pp. 5-22.

[12] Woch F.: Ocena efektywności scaleń gruntów realizowanych $w$ Polsce $w$ ramach Wspólnej Polityki Rolnej Unii Europejskiej [Evaluation of the effectiveness of land consolidation carried out in Poland under the Common Agricultural Policy of European Union]. Infrastruktura i Ekologia Terenów Wiejskich, nr 2/III, 2012, pp. 101-112.

\section{Ocena efektów przestrzennych prac scaleniowych realizowanych w Polsce w latach 2007-2013}

Streszczenie: Duża część obszarów wiejskich w Polsce wymaga głębokich zmian strukturalnych. Obszary te (zwłaszcza południowej i południowo-wschodniej Polski) charakteryzuje nadmierne rozdrobnienie gruntów rolników indywidualnych, niekorzystny rozłóg gruntów w gospodarstwach rolnych, zły stan (lub brak) infrastruktury technicznej i instytucjonalnej, a także zachodzą na nich niepokojące procesy demograficzne (takie jak migracja ludności wiejskiej do miast i starzenie się lokalnej ludności). Możliwe jest uzyskanie poprawy istniejącej sytuacji, dzięki realizacji programów rozwoju obszarów wiejskich, m.in. scalenia gruntów.

Celem pracy jest ocena efektów przestrzennych prac scaleniowych prowadzonych w Polsce w latach 2007-2013. W badaniach oparto się na reprezentatywnej próbie 38 obiektów scaleniowych z różnych części Polski. Wybrane obiekty badawcze poddane zostały analizie pod kątem wynikających z przeprowadzonego procesu scalenia zmian podstawowych parametrów charakteryzujących strukturę przestrzenną gruntów: współczynnika zmniejszenia ogólnej liczby działek oraz współczynnika zwiększenia średniego pola powierzchni działki na obiekcie badawczym.

Słowa

kluczowe: scalenie gruntów, efekty przestrzenne scalenia, rozwój obszarów wiejskich, obszary wiejskie w Polsce 